\title{
EVALUATION OF CLINICAL RECOVERY AND HEALING OF ORAL LESIONS BY 3 DIFFERENT THERAPEUTIC REGIMENS IN CATTLE WITH FOOT AND MOUTH DISEASE (FMD)
}

\author{
AL-LETHIE A. AL-LETHIE ${ }^{1}$; SAYED F. El-HAWARI ${ }^{2}$; KHALED A.S. El-KHABAZ ${ }^{3}$; \\ ENAS ELMELIGY ${ }^{4}$; ARAFAT KHALPHALLAH ${ }^{5}$ and USAMA T. MAHMOUD ${ }^{6}$ \\ ${ }^{1}$ Department of Surgery, Anaesthesiology and Radiology, Faculty of Veterinary Medicine, Aswan University, Aswan 81528, Egypt. \\ ${ }^{2}$ Department of Surgery, Anaesthesiology and Radiology, Faculty of Veterinary Medicine, Sohag University, Sohag 82524, Egypt. \\ ${ }^{3}$ Department of Animal Medicine (Infectious Diseases) Faculty of Veterinary Medicine, Assiut \\ University, Assiut 71526, Egypt. \\ ${ }^{4}$ Veterinary Teaching Hospital, Faculty of Veterinary Medicine, Assiut University, Assiut 71526, Egypt. \\ ${ }^{5}$ Department of Animal Medicine (Internal Medicine) Faculty of Veterinary Medicine, \\ Assiut University, Assiut 71526, Egypt. \\ ${ }^{6}$ Department of Animal Hygiene, Faculty of Veterinary Medicine, Assiut University, Assiut 71526, Egypt.
}

Received: 31 December 2017; Accepted: 24 January 2018

\begin{abstract}
The study compares the clinical outcome of the use of different topical treatments for oral lesions in cattle suffering from foot and mouth disease (FMD). One hundred diseased cattle, during an outbreak of FMD in Assiut governorate, Egypt, were used in this study. The animals divided into four equal groups. The oral lesions after being washed with physiological saline solution to remove necrotic tissues, were sprayed twice daily by Phenytoin (PHEN group), Bacitracin and Neomycin (BAC-NEO group), Oxytetracycline and Crystal violet (OXY-CRY group), and the lesions leaved without any topical applications (control group). All animals in the four groups treated daily and for 3 consecutive days by the intramuscular injection of both Oxytetracycline as a broad spectrum antibiotics and Flunixin meglumine as antipyretic and anti-inflammatory drugs. It was observed that all animals in PHEN group show complete healing of oral lesions and the animals return to its normal appetite after 4 days whereas animals in BAC-NEO and OXY-CRY groups take a longer time to show improvement. The lesions in control group remain unhealed with bad appetite till the end of the observation period. It is concluded that Phenytoin (Healosol®) has a potent wound healing activity comparable to Bacitracin-Neomycin (Bivatracin $\left.{ }^{\circledR}\right)$ and Oxytetracycline-Crystal violet (Oxy G®) in treatment of the oral lesions of FMD in cattle.
\end{abstract}

Key words: foot and mouth disease (FMD), phenytoin, cattle, oral lesions, wound healing.

\section{INTRODUCTION}

Foot and Mouth disease is a highly contagious disease causing severe economic losses to the animal industries. It affects cloven-footed animals and characterized by fever, anorexia, salivation, vesicular eruptions and formation of erosions and ulcers in the mucosa of oral cavity, feet and udder (Kitching et al., 2005). The causative agent is an aphthovirus belong to family Picornaviradae, there are seven major and immunologically distinct serotypes designated as A, O, C, SAT1, SAT2, SAT3 and Asia1(OIE, 2009).

The treatment aims to return the affected animals to normal appetite quickly and decrease the rate of weight

Corresponding author: Dr. SAYED F. El-HAWARI

E-mail address: sayedelhawari@gmail.com

Present address: Department of Surgery, Anaesthesiology and Radiology, Faculty of Veterinary Medicine, Sohag University, Sohag 82524, Egypt. loss through treatment of FMD lesions at the mouth and claws as well as to prevent complications (Sharma, 2010). There is no standard treatment for lesions of FMD, however anti-inflammatory drugs and mild disinfectant and protective dressing of the lesions to prevent secondary infection are recommended (Gakuya et al., 2011; Duz et al., 2012 and Misk et al., 2015).

Ideally, the healing process consists of a serial of overlapping events as inflammation, regeneration, wound shrinkage and finally connective tissue formation, and remodeling. Appropriate treatment of wound can accelerate the healing process and prevent infection. Different types and approaches have been used to achieve shorter wound healing times (Alizadeh et al., 2007 and Hasamnis et al., 2010).

The combination of Oxytetracycline (anti-bacterial) and Crystal Violet (antiseptic dye) has been previously used in treatment of digital dermatitis in dairy cattle (Blowey and Sharp, 1988) and lesions of foot and mouth disease 
(Misk et al., 2015). Neomycin-bacitracin combination work in a synergistic fashion for the prevention and treatment of most common disease-causing pathogens found in wounds and on the skin (Bonomo et al., 2007). Antimicrobial effect of the ingredients of the aforementioned combinations prevents the secondary bacterial infection leading to healing of the lesions without complications (Stashak and Theoret, 2008).

Phenytoin was first introduced as a human anticonvulsant medication. Gingival hyperplasia occurred in some patients treated with it stimulated the study regarding the potential use of phenytoin in wound healing (Ghapanchi et al., 2013). Various studies have been conducted to demonstrate the effectiveness of topical phenytoin in the treatment of a variety of wounds of various etiologies (Qunaibi et al., 2009; Jayalal et al., 2015; Al-lethie, 2016 and Prabhu et al., 2016).

Mode of phenytoin action on the process of healing was previously described by many authors in human and dental medicine. They include increasing fibroblast proliferation, inhibiting collagenase activity, promoting collagen deposition, enhancing granulation tissue formation, decreasing bacterial contamination, reducing wound exudates formation and up regulating growth factor receptors (Hasamnis et al., 2010 and Hajong et al., 2016).

The present study aims to compare between three different therapeutic approaches in management of oral lesions of FMD under the field conditions with estimation of the degree of healing, animal's appetite and clinical improvement in each type of treatment.

\section{MATERIALS AND METHODS}

\section{Animals:}

A total of 100 FMD diseased cattle (age 1-4 years) at different localities in Assiut governorate, Egypt, during the period from January, 2017 till April, 2017 were used in the present study. These animals were randomly divided into 4 equal groups (each group consists of 25 animals).

\section{Treatment protocol:}

Management of such oral lesions in all groups include; thorough cleaning with physiological saline to remove the necrotic tissues, mucous membrane shreds, trimming and freshening of the wound edges. All groups were treated systemically by intramuscular injection of oxytetracycline $(10 \mathrm{mg} / \mathrm{kg} / 24 \mathrm{~h})$ (Spectropan ${ }^{\circledR}$, Pharma Swede, Egypt) and Flunixin meglumine $(2.2 \mathrm{mg} / \mathrm{kg} / 24 \mathrm{~h})$ (Flunixin ${ }^{\circ}$, Norbrook, UK) for 3 consecutive days. The first group (PHEN) was treated by application of phenytoin 2\% spray (Healosol spray®, Egyptian company for advanced pharmaceuticals, Cairo, Egypt) locally on the mouth lesions, twice daily, until complete healing occurred. The second group (BAC- NEO) was treated by topical application of Bacitracin and Neomycin spray (Bivatracin spray®, Egyptian company for advanced pharmaceuticals, Cairo, Egypt) on the oral lesions, twice daily, until complete healing occurred. The third group (OXY_CRY) was treated by topical application of Oxytetracycline and Crystal Violet spray (Oxy-G spray®, ADWIA pharmaceuticals company, Cairo, Egypt) twice daily and until complete healing occurred. The fourth group (control) was left without topical application of any medicaments.

Evaluation of wound healing and clinical recovery:

All animals were examined clinically according to Radostitis et al. (2007). Clinical examinations include; respiratory rate (RR), heart rate (HR) and rectal temperature (RT). Wound healing and appetite were evaluated using a numerical score previously described by Duz et al. (2012) with some modifications. Wound healing score ranged from 1 to 4 (erosion and ulcer $=1$, healthy granulation tissue formation $=2$, re-epithelization $=3$, complete healing=4). Appetite score ranged from 1 to 4 (No appetite $=1$, little appetite $=2$, good appetite $=3$ and very good appetite=4). All data for clinical parameters, healing and appetite scores were recorded before (baseline) and at 2, 4 and 7 days of treatment for all groups.

\section{Statistical Analysis:}

The values were expressed as mean \pm SE. All data were analyzed using one way analysis of variances (ANOVA) and compared with the control group followed by Tukey's post hoc. test using SPSS 16.0 statistical software (Spss, Inc, Chicago, IL).

\section{RESULTS}

Before application of topical treatment to oral lesions, all animals in the four groups suffering from rise of body temperature, heart rate and respiratory rate without any significant differences between groups (Table 1). In PHEN, BAC- NEO and OXY_CRY groups, at the $2^{\text {nd }}$ and $4^{\text {th }}$ day, there were a significant decrease in the body temperature $(\mathrm{p}=.0001)$, respiratory rate $(\mathrm{p}=.0001)$ and heart rate $(\mathrm{p}=.0001)$ in comparison to the control group. Also, animals of PHEN group show a better clinical improvement (heart rate, respiratory rate and rectal temperature) than BAC- NEO and OXY_CRY groups at $2^{\text {nd }}$ and $4^{\text {th }}$ day of treatment. After 7 days of treatment there is no significant differences recorded in rectal temperature, heart rate and respiratory rate between PHEN, BAC- NEO and OXY_CRY groups. However, all topically treated groups still have a significant lower rectal temperature $(\mathrm{p}=.0001)$, respiratory rate $(\mathrm{p}=.0001)$ and heart rate $(\mathrm{p}=.019)$ than the control group.

Regarding to healing and appetite scores (Table 2); all groups have no significant difference before treatment application with a large area of denuded epithelium (Figs.1, 2, 3\&4). Healing score was significantly increased at the $2^{\text {nd }}, 4^{\text {th }}$ and $7^{\text {th }}$ day of topical application of PHEN ( $\mathrm{p}=.0001)$ (Fig 5), BAC- NEO (p=.0001) (Fig. 6) and OXY-CRY (p=.008) (Fig. 7) than the control group. Appetite score was significantly increased at the 
$2^{\text {nd }}, 4^{\text {th }}$ and $7^{\text {th }}$ day of topical treatment in PHEN $(\mathrm{p}=.0001)$, BAC- NEO $(\mathrm{p}=.002)$ and OXY-CRY $(\mathrm{p}=.02)$ groups than the control group. In PHEN group, healing and appetite scores were higher than BAC- NEO and OXY-CRY groups at the $2^{\text {nd }}\{$ (for appetite $p=.0001$ and $=.0001$ respectively) (for healing $\mathrm{p}=.003$ and .0001 respectively) $\}$ and the $4^{\text {th }}$ day $\{$ (for appetite $p=.0001$ and .0001 respectively) (for healing $\mathrm{p}=.0001$ and .0001 respectively) $\}$ of treatment application. While, after 7 days, there were no significant differences between all three types of topical treatments either in the healing score or in the appetite score. But significant differences still present between PHEN, BAC- NEO and OXY-CRY groups and the control group at the $7^{\text {th }}$ day in the healing score (Fig. 8) $(\mathrm{p}=.0001)$ and appetite score $(\mathrm{p}=.0001)$.

Table 1: Showing the mean $\pm \mathrm{SE}$ of rectal temperature $(\mathrm{RT})$, heart rate $(\mathrm{HR})$ and respiratory rate (RR) for clinical evaluation before and after each type of topical treatment in FMD diseased cattle.

\begin{tabular}{|c|c|c|c|c|c|}
\hline & \multirow{2}{*}{\multicolumn{2}{|c|}{$\begin{array}{l}\text { Before treatment } \\
\text { (Baseline) }\end{array}$}} & \multicolumn{3}{|c|}{ After treatment } \\
\hline & & & 2 days & 4 days & 7 days \\
\hline $\begin{array}{l}\text { PHEN } \\
(n=25)\end{array}$ & $\begin{array}{l}\text { RT } \\
\text { HR } \\
\text { RR }\end{array}$ & $\begin{array}{l}40.53 \pm 0.06 \\
82.28 \pm 0.27 \\
42.56 \pm 0.32\end{array}$ & $\begin{array}{l}39.18 \pm 0.04^{\mathrm{c}} \\
74.28 \pm 0.31^{\mathrm{c}} \\
24.64 \pm 0.33^{\mathrm{c}}\end{array}$ & $\begin{array}{l}38.68 \pm 0.04^{\mathrm{c}} \\
72.40 \pm 0.28^{\mathrm{c}} \\
22.76 \pm 0.29^{\mathrm{c}}\end{array}$ & $\begin{array}{l}38.56 \pm 0.02^{b} \\
71.52 \pm 0.56^{b} \\
22.36 \pm 0.18^{b}\end{array}$ \\
\hline $\begin{array}{c}\text { BAC- NEO } \\
\quad(n=25)\end{array}$ & $\begin{array}{l}\text { RT } \\
\text { HR } \\
\text { RR }\end{array}$ & $\begin{array}{l}40.61 \pm 0.07 \\
82.40 \pm 0.32 \\
42.32 \pm 0.35\end{array}$ & $\begin{array}{l}39.42 \pm 0.05^{\mathrm{b}} \\
77.32 \pm 0.30^{\mathrm{b}} \\
26.92 \pm 0.29^{\mathrm{b}}\end{array}$ & $\begin{array}{l}39.22 \pm 0.04^{\mathrm{b}} \\
74.44 \pm 0.26^{\mathrm{b}} \\
24.48 \pm 0.31^{\mathrm{b}}\end{array}$ & $\begin{array}{l}38.63 \pm 0.03^{\mathrm{b}} \\
72.33 \pm 0.19^{\mathrm{b}} \\
22.96 \pm 0.26^{\mathrm{b}}\end{array}$ \\
\hline $\begin{array}{c}\text { OXY_CRY } \\
(n=25)\end{array}$ & $\begin{array}{l}\text { RT } \\
\text { HR } \\
\text { RR }\end{array}$ & $\begin{array}{l}40.54 \pm 0.07 \\
82.44 \pm 0.24 \\
42.24 \pm 0.31\end{array}$ & $\begin{array}{l}39.47 \pm 0.06^{\mathrm{b}} \\
77.44 \pm 0.32^{\mathrm{b}} \\
26.04 \pm 0.30^{\mathrm{b}}\end{array}$ & $\begin{array}{l}39.13 \pm 0.05^{\mathrm{b}} \\
73.92 \pm 0.33^{\mathrm{b}} \\
24.24 \pm 0.35^{\mathrm{b}}\end{array}$ & $\begin{array}{l}38.62 \pm 0.02^{\mathrm{b}} \\
72.82 \pm 0.24^{\mathrm{b}} \\
22.48 \pm 0.27^{\mathrm{b}}\end{array}$ \\
\hline $\begin{array}{c}\text { Control } \\
(n=25)\end{array}$ & $\begin{array}{l}\text { RT } \\
\text { HR } \\
\text { RR }\end{array}$ & $\begin{array}{c}40.51 \pm 0.06 \\
82.28 \pm 0.33 \\
42.00 \pm 0.28\end{array}$ & $\begin{array}{l}40.13 \pm 0.04^{\mathrm{a}} \\
79.04 \pm 0.46^{\mathrm{a}} \\
34.72 \pm 0.24^{\mathrm{a}}\end{array}$ & $\begin{array}{l}39.64 \pm 0.05^{\mathrm{a}} \\
77.60 \pm 0.43^{\mathrm{a}} \\
32.36 \pm 0.26^{\mathrm{a}}\end{array}$ & $\begin{array}{l}39.28 \pm 0.03^{\mathrm{a}} \\
75.88 \pm 0.25^{\mathrm{a}} \\
26.48 \pm 0.35^{\mathrm{a}}\end{array}$ \\
\hline
\end{tabular}

Different superscripts within the same rows depict significant differences among groups at $\mathrm{p}<0.05$

Table 2: Showing the mean \pm SE of the healing score (HEA) and appetite score (APP) before and after each type of topical treatment in FMD diseased cattle.

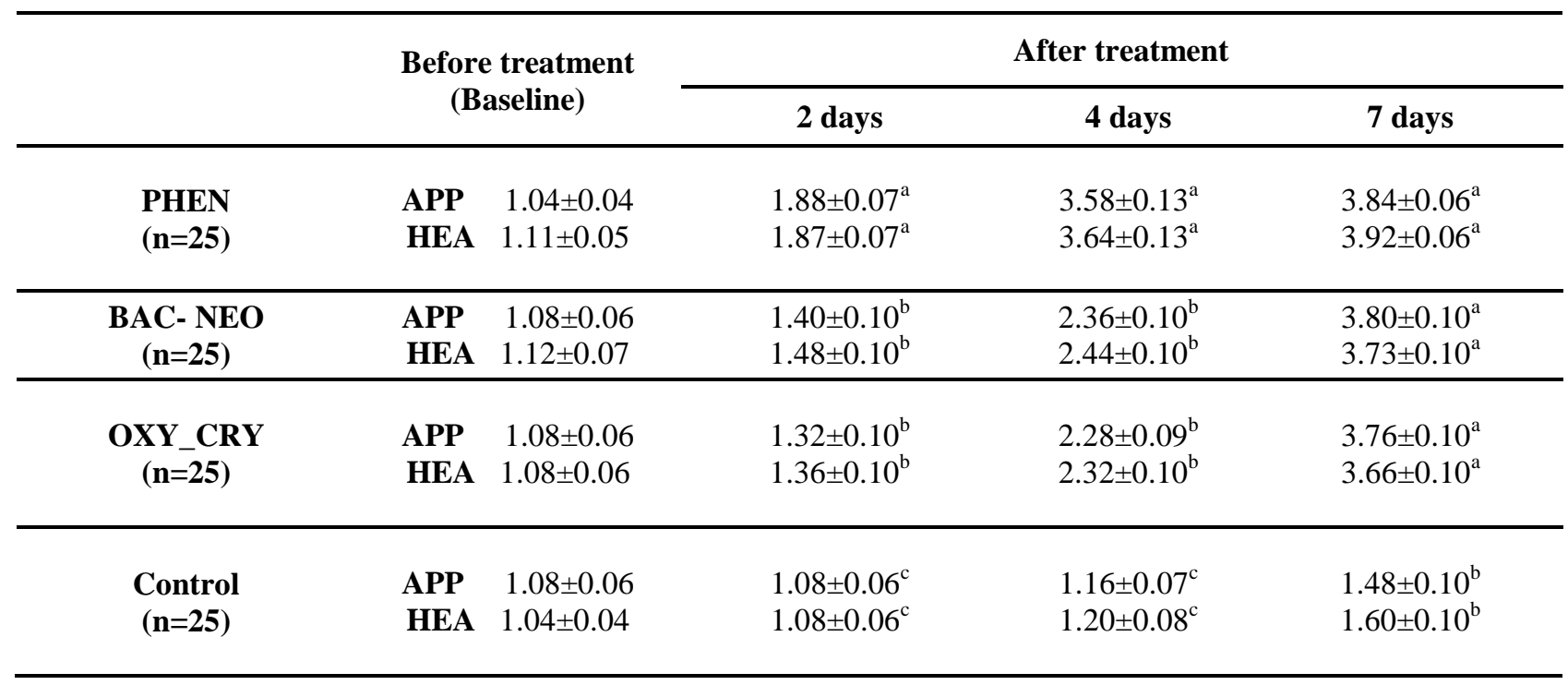

Different superscripts within the same rows depict significant differences among groups at $\mathrm{p}<0.05$ 

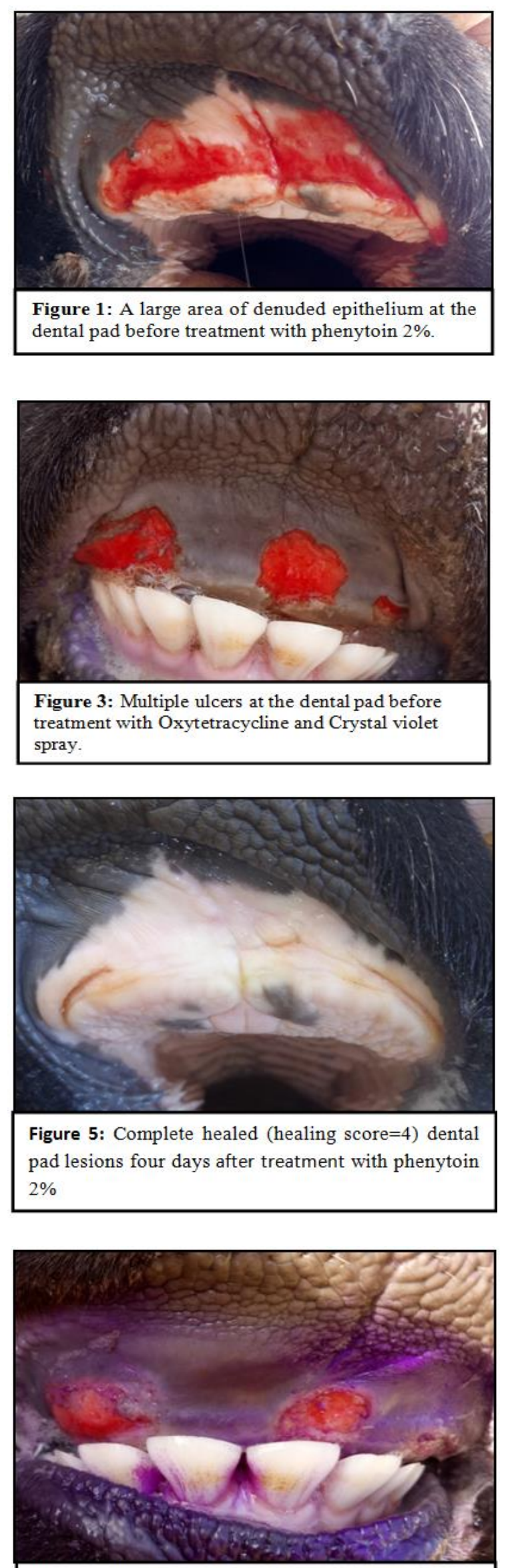

Figure 7: Slightly healed (healing score $=2$ ) dental pad ulcers four days after treatment with Oxytetracycline and Crystal violet spray.

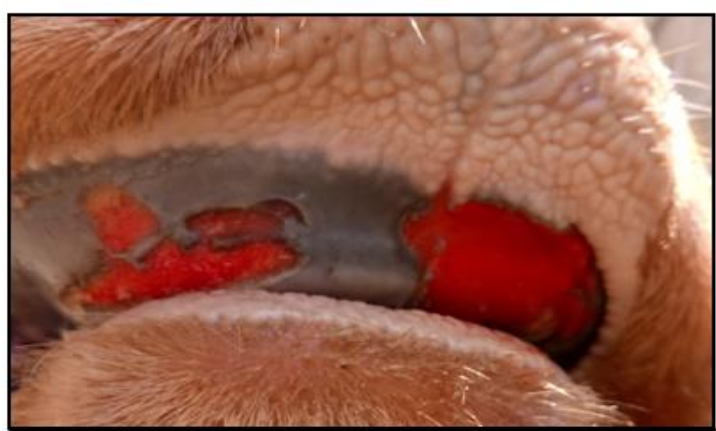

Figure 2: Ulcers on the dental pad before treatment with Bacitracin and Neomycin spray.

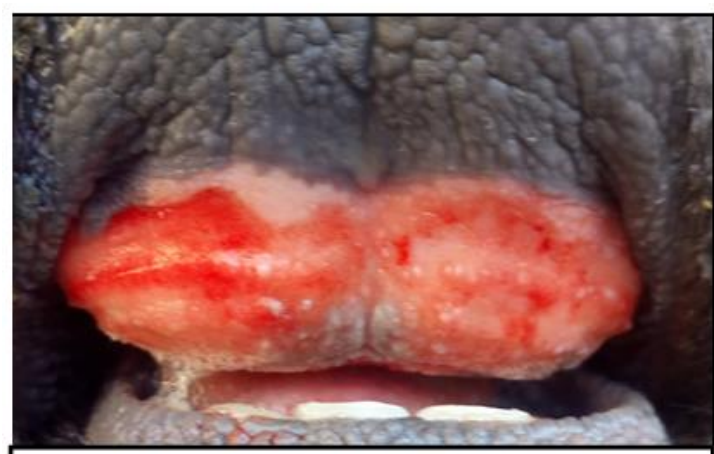

Figure 4: A large area of denuded epithelium at the dental pad before treatment in control group
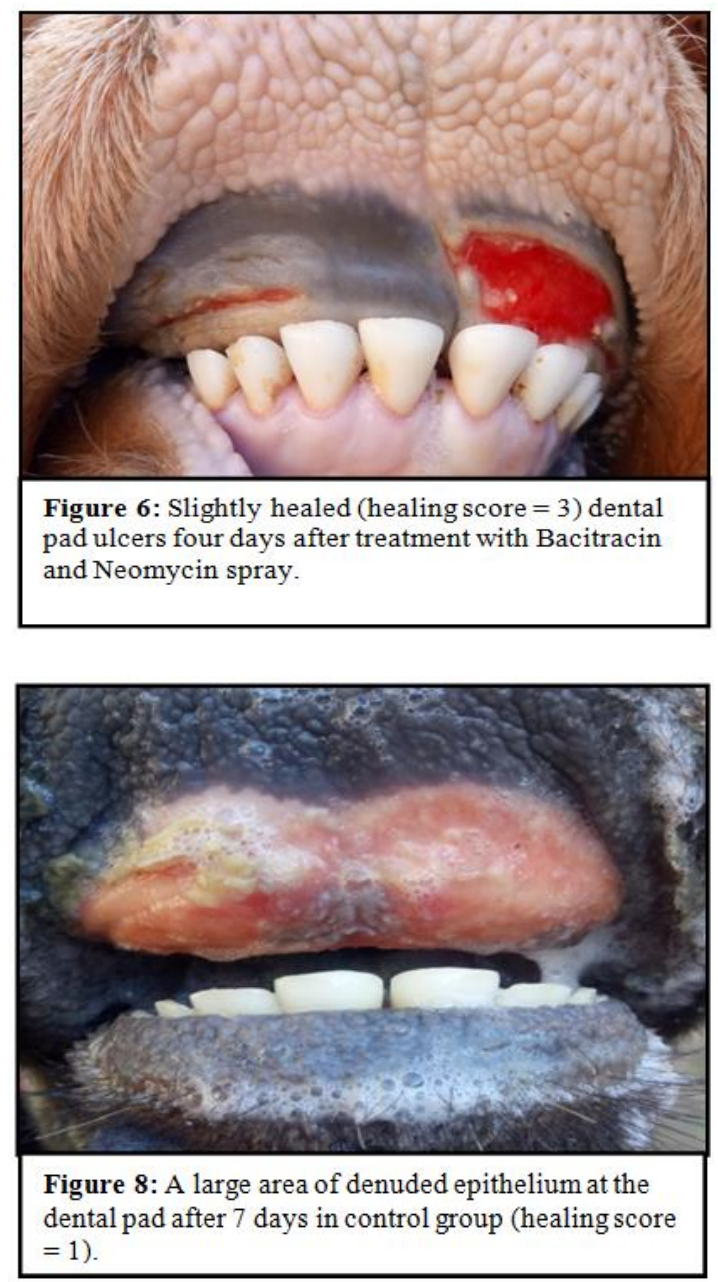


\section{DISCUSSION}

All animals included in this study were found to be suffering from fever, salivation, anorexia and vesicular eruptions and formation of erosions and ulcers in the mucosa of oral cavity in addition to the feet and the udder which are the characteristic clinical signs of FMD (Visvesvaran and Thirumalaiswamy, 2015 and ElKhabaz and Al-Hosary, 2017).

Although eradication of FMD by slaughtering of all infected and in contact animals is the main control procedure in western countries, eradication does not seem possible in endemic countries. Vaccination of uninfected and in contact animals and treatment of infected animals is recommended in endemic countries (Samad et al., 2012).

Phenytoin showed a marvelous effect that is characterized by disappearance of inflammation signs (redness and pain) and improves the animal's appetite two days after the beginning of its topical application to oral lesions. These results were consistent with previous studies which reported that phenytoin reduce inflammation, oedema, wound transudation and exudation (Shaw et al., 2007 and Rituraj et al., 2015). Local pain relief of phenytoin could be explained by its ability to reduce permeability of nerve membrane, so that it acts like a local anesthetic (Oluwatosin et al., 2000 and Rashidi et al., 2012). In PHEN group, complete healing of lesions and animal regain normal appetite occurred after four day of treatment. These results were consistent with previous studies which described that phenytoin enhance formation of well-vascularized granulation tissue following its topical application to the cutaneous wounds through enhancement of fibroblast proliferation, significant increase in neovascularization and collagen deposition (Carneiro and Nyawawa, 2003; Habibipour et al., 2003; Hasamnis et al., 2010; Sayar et al., 2014 and Hajong et al., 2016). Phenytoin has an indirect effect on epithelialization because of its ability to decrease inflammation, reduce oedema and enhance contraction of the wound and direct effect through enhancing keratinocyte proliferation (Firmino et al., 2014). Anti bacterial activity of phenytoin is another important factor that is reported to contribute in improving wound healing (Muthukumarasamy et al., 1991).

The results of this study revealed that the animals In BAC- NEO and OXY-CRY groups recovered with complete healing of lesions and animal regain normal appetite occurred after seven days. This may be attributed to the antimicrobial effect of the ingredients of these products which prevent the secondary bacterial infection leading to healing of the lesions without complications and this agree with Stashak and Theoret (2008) who reported that secondary bacterial infection is one of the factors that delay wound healing. But the healing time in BAC- NEO and OXY-CRY groups was later than PHEN group as the antimicrobial drugs cannot produce angiogenesis, fibroplasia, contraction, or epithelialization, but these processes naturally proceed when bacterial interference is halted by the action of antimicrobial drugs (Brumbaugh, 2005).

Oral lesions in control group remain unrecovered up to seven days besides being suffered from wound complications in spite of systemic antibiotic administration, this may attributed to wound site infections which remain an important complication of wound healing. So that topical agents are also important to achieve greater and quicker healing (Eze and Nlebedum, 2007).

In conclusion treatment of oral lesions, caused by FMD, by antiseptic and antibiotic preparations as BacitracinNeomycin and Oxytetracycline-Crystal Violet provide healing after seven days through prevention of secondary microbial contamination. However, phenytoin preparation provides faster healing (after 2-4 days) as it has anti bacterial activity, local pain relief, fibroplastic and epithelialization effect. Phenytoin also reduces inflammation, oedema, wound transudation and exudation. Early healing of oral lesions permit animals to regain normal appetite quickly which enhance the immune response and animal can overcome viral infection and return to its normal clinical parameters quickly.

\section{REFERENCES}

Alizadeh A.; Mohagheghi M.; Khaneki M.; Saeed P.K. (2007): A study of the effect of magnesium hydroxide on the wound healing process in rats. Med J Islamic World Acad Sci., 16: 165-70.

Al-lethie (2016): Evaluation the effect of five topical medicaments on the metacarpal wounds healing in donkeys (An experimental study). Ph.D. Thesis. Veterinary Surgery. Faculty of veterinary medicine. Assiut University.

Blowey, R.W. and Sharp, M.W. (1988): digital dermatitis in dairy cattle. Vet Rec., 122(21): 505-8.

Bonomo, R.A.; Van Zile, P.S.; Li, Q.; Shermock, K.M.; McCormick, W.G. and Kohut B. (2007): Topical triple-antibiotic ointment as a novel therapeutic choice in wound management and infection prevention: a practical perspective. Expert Rev Anti Infect Ther, 5: 773-782.

Brumbaugh, G.W. (2005): Use of antimicrobials in wound management. Veterinary Clinics of North America, Equine Practice, 21, (1), 63-75.

Carneiro, P.M. and Nyawawa, E.T. (2003): Topical phenytoin versus EUSOL in the treatment of nonmalignant chronic leg ulcers. East Afr Med J, 80(3):124-9.

El-Khabaz, K.A.S. and Al-Hosary, A.A.T. (2017): Detection and identification of Foot and Mouth disease virus serotypes in Assiut governorate, Egypt. Journal of Advanced Veterinary and Animal Research, 4(1): 32-38.

Erkan Duz; Hasan Icen; Neval B. Arserrim; Firat Cakmak; Bahtiyar Bakir and Ersin Uysal (2012): Comparison of classic, Theranekron and classicplus Theranekron treatment on the foot and mouth 
disease lesions in cattle in Van, Diyarbakir and Ankara Regions in Turkey. J Anim Vet Adv, 11: 3258-3261.

Eze, C.A. and Nlebedum, U. (2007): Antibacterial and healing potentials of Charmil ${ }^{\circledR}$ as a surgical wound dressing agent in goats. Journal of Agriculture, Food, Environment and Extension, 6 (1): $63-70$.

Firmino, F.; Almeida, A.M.; Silva, R.J. and Alves (2014): Scientific production on the applicability of phenytoin in wound healing. Rev Esc Enferm USP 48(1):162-169.

Gakuya, D.W.; Mulei, C.M. and Wekesa, S.B. (2011): Use of ethnoveterinary remedies in the management of foot and mouth disease lesions in a dairy herd. African Journal of Traditional, Complementary and Alternative Medicines, 8 (2): 165-169.

Ghapanchi, J.; Noorani, H.; Farzin, M.; Rezazadeh, F. and Pyrayeh, H. (2013): Effect of topical phenytoin on chemotherapy-induced oral mucositis. Elixir Dentistry, 54: 12572-12573.

Habibipour, S.; Oswald, T.M. and Zhang, F.; Joshi P.; Zhou, X.C.; Dorsett-Martin, W. and Lineaweaver, W.C. (2003): Effect of sodium diphenylhydantoin on skin wound healing in rats. Plastic Reconstructive Surgery, 112: 1620-1627.

Hasamnis A.; Mohanty B.; Muralikrishna, Patil S. (2010): Evaluation of wound healing effect of topical Phenytoin on excisional wound in albino rats. J Young Pharm, 2: 59-62.

Jayalal, J.A.; Selwyn, J. and Abdul Kadar, M. (2015): Efficiency of topical Phenytoin on healing in diabetic foot ulcer: A randomized controlled trial. International Journal of Scientific Study, 3 (3): 84-89.

Kitching, R.P.; Hutber, A.M. and Thrusfield, M.V. (2005): A review of foot and mouth disease with special consideration for the clinical and epidemiological factors relevant to predictive modelling of the disease. The veterinary journal, 169: 197-209.

Muthukumarasamy, M.G.; Sivakumar, G. and Manoharan, G. (1991): Topical phenytoin in diabetic foot ulcers. Diabetes Care, 14(10): 909911.

Misk, N.A.; Misk, T.N. and Rateb, H.Z. (2015): Assessment and topical treatment of lesions of foot and mouth disease in cattle. Assiut Vet. Med. J. Vol. 61 (145): 75-81.

O.I.E. (2009): Terrestrial Manual, chabter 2.1.5. Foot and mouth disease: 1-29

Oluwatosin, O.M.; Olabanji, J.K.; Oluwatosin, O.A.; Tijani, L.A. and Onyechi, H.U. (2000): A comparison of topical honey and phenytoin in the treatment of chronic leg ulcers. African journal of medicine and medical sciences, 29 (1): 31-34.
Prabhu, R.; Ravi, C.; Pai S. and Rodrigues, G. (2016): The efficacy of topical phenytoin in the healing of diabetic foot ulcers: a randomized double-blinded trial. International Journal of Diabetes in Developing Countries, 37(1):46-4.

Qunaibi, E.A.; Disi A.M. and Taha, M.O. (2009): Phenytoin enhances collagenization in excision wounds and tensile strength in incision wounds. Pharmazie., 64 (9): 584-586.

Radostitis, O.M.; Gay, C.C.; Hinchcliff, K.W. and Constable, P.D. (2007): Veterinary medicine. A text book of the diseases of cattle, horses, sheep, pigs and goats. $10^{\text {th }}$ Ed., Saunders Elsevier. pp: 331.

Ranendra Hajong, Narang Naku, Debobratta Hajong, Madhur Anand, $K$ Lenish Singh and Nilanjan Majumdar (2016): Effect of topical phenytoin on wound healing. IOSR Journal of Dental and Medical Sciences, 15(9): 161-164.

Rashidi, F.; Sehhati, F.; Ghojazadeh, M.; Javadzadeh, Y. and Haghsaie, M. (2012): The Effect of Phenytoin Cream in Comparison with Betadine Solution on Episiotomy Pain of Primiparous Women. Journal of Caring Sciences, 1(2): 61-65.

Rituraj, L.; Aggarwal, S. and Chatterjee, S. (2015): Topical phenytoin: Role in diabetic ulcer care. Int J Interdiscip Multidiscip Stud, 2: 93-97.

Samad Lotfollahzadeh; Mohammad Reza Alizadeh; Mehrdad Mohri and Mohammad Reza Mokhber Dezfouli (2012): The therapeutic effect of Tarentula cubensis extract (Theranekron) in footand-mouth disease in cattle: a randomised trial in an endemic setting. Homeopathy, 101, 159-164.

Sayar, H.; Gergerlioglu, N.; Seringec, N.; Ozturk, P.; Bulbuloglu, P. and Karabay, G. (2014): Comparison of efficacy of topical phenytoin with hypericin in second-degree burn wound healing: An experimental study in rats. Med Sci Monit Basic Res, 20: 36-46.

Sharma, N. (2010): Foot and mouth disease-Mastitis cascade in dairy cattle: A field study. International Journal of Zoological Research 6(4): 356-359.

Shaw, J.; Hughes, C.M.; Lagan, K.M. and Bell, P.M. (2007): The clinical effect of topical phenytoin on wound healing: a systematic review. $\mathrm{Br} \mathrm{J}$ Dermatol, 157(5): 997-1004.

Stashak, T.S. and Theoret, C. (2008): Equine wound management. $2^{\text {nd }}$ edition. Wiley-Blackwell. PP: 80-100

Visvesvaran, S. and Thirumalaiswamy, T. (2015): Ethnoveterinary practices adopted during an epidemic outbreak of Foot and Mouth Disease among cattle in Sirkazhi and adjoining villages of Nagapattinam district of Tamil Nadu, India. Int J. Pharmacol and Clin Sci, 4(2): 23-24. 


\section{تقييم الثفاء السريري والتئام آفات الفم بإستخدام ب نظم علاجية مختلفة في الأبقار المصابة بالحمي القلاعية \\ الليثي الحظ الليثي ، سبي فتحي الهواري ، خالد أحدد الخباز ، إيناس المليجي ، عرفات عبد اللاه ، أسامة طه محمود}

\section{E-mail: sayedelhawari@gmail.com Assiut University web-site: www.aun.edu.eg}

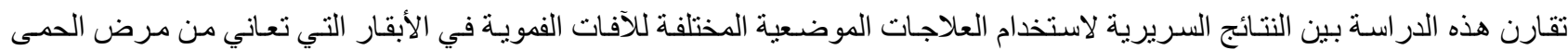

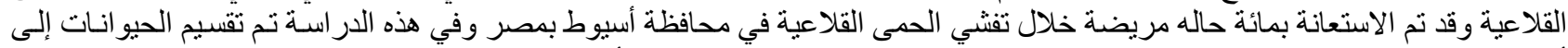

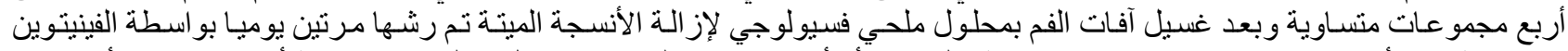

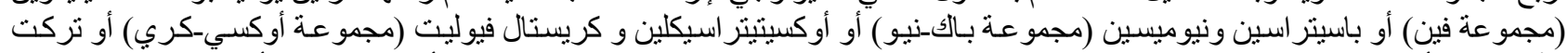

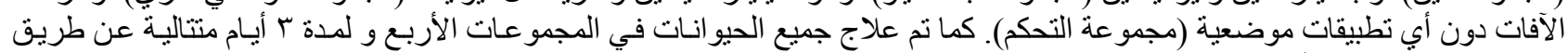

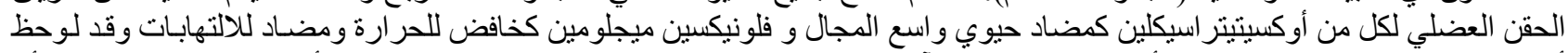

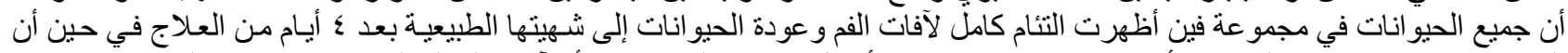

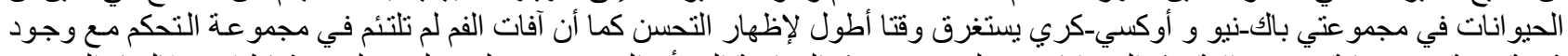

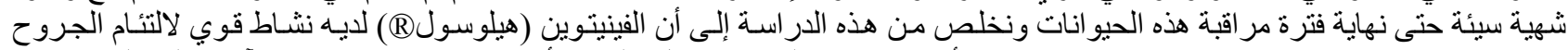

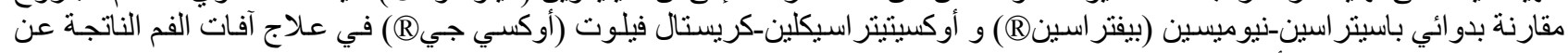
مرض الحمي القلاعية بالأبقار. 